Research Article

\title{
Presenteeism: A Reflection of Leadership Styles among Healthcare Professionals in Karachi
}

\author{
Syeda Nadia Bokhari, Nawaz Ahmad and Syed Irfan Hyder \\ Institute of Business Management, Karachi, Pakistan
}

Correspondence should be addressed to: Syeda Nadia Bokhari; s.nadiabokhari@gmail.com

Received date: 5 September 2016; Accepted date: 28 December 2016; Published date: 1 February 2017

Academic Editor: Muhammad Hasmi Abu Hassan Asaari

Copyright (C) 2017. Syeda Nadia Bokhari, Nawaz Ahmad and Syed Irfan Hyder. Distributed under Creative Commons CC-BY 4.0

\begin{abstract}
This study investigates the impact of three leadership styles; the transactional leadership style, the transformational leadership style and laissez faire on presenteeism among the healthcare professionals in Pakistan. Using a structured close-ended questionnaire, data were obtained from 128 healthcare employees in Karachi. After encoding, the data were entered into the statistical package for social sciences (SPSS) version 21. Using the descriptive and inferential statistics, the data were analyzed. Linear regression was applied to gauge the impact of the three leadership styles on employee presenteeism. Results revealed that presenteeism is independent of all the three leadership styles being practiced among the healthcare professionals in Karachi. Further research into the factors causing presenteeism can lead to a better conceptualizing of this phenomenon.
\end{abstract}

Keywords: leadership styles, transactional, transformational, laissez faire, presenteeism, Pakistan

\section{Introduction}

Presenteeism is a phenomenon that has evolved with time. Traditionally, the term presenteeism was used as an antonym of absenteeism (Johns, 2010). It was used to indicate full attendance. With the passage of time, the subject caught the attention of scholars especially in occupational medicine who referred to it as 'employees attending work while being ill' (Aronsson et al., 2000).
Johns (2010) identifies two schools of thoughts on the subject, one being that of the European scholars in management and occupational health and the other being that of the American medical scholars and consultants. The European scholars were more interested in determining the frequency of the 'act' of presenteeism due to job insecurity and other occupational factors where as their American counterparts focused on the consequences to productivity

Cite this Article as: Syeda Nadia Bokhari, Nawaz Ahmad and Syed Irfan Hyder (2017)," Presenteeism: A Reflection of Leadership Styles among Healthcare Professionals in Karachi", Journal of Southeast Asian Research, Vol. 2017 (2017), Article ID 255072, DOI: 10.5171/2017.255072 
of presenteeism as a function of various illnesses while not taking into consideration the causes that forced them to show up at work ill.

The beginning of the current millennium saw scholars from various fields take more interest in the subject. Presenteeism was defined by Hemp (2004) as 'the problem of workers being on the job but, because of illness or other medical conditions, not fully functioning'. The American Heritage Dictionary of the English Language (2006) defines presenteeism as the practice of coming to work despite illness, injury, anxiety, etc., often resulting in reduced productivity'. Gilbreath \& Karimi, (2012) further state that 'presenteeism occurs when employees are physically present at their work place but are mentally absent, that is, their cognitive energy at work is compromised'.

Literature on presenteeism observes that presenteeism has mostly been measured as an outcome of sickness, thus limiting the full conceptualization of the complexity of the term. Just like absenteeism, presenteeism too may come with a number of underlying causes other than illness (Gilbreath \& Karimi, 2012; Prater \& Smith, 2011). Some causes identified by Prater \& Smith include stress, anxiety and financial status which affect employee health and work productivity. Whitehouse (2005) associated office politics as one of the causes that may lead employees to encounter presenteeism. Johns attributes organizational policies regarding pay, sickness pay, employee permanency; job design and presenteeism culture as factors leading employees to indulge in presenteeism. According to Cooper (1994), presenteeism is defined as 'people turning up to work, who are so distressed by their jobs or some aspect of organizational climate that they contribute little, if anything, to their work'. Employees suffering from presenteeism are prone to making more mistakes, are less innovative and show signs of reduced productivity (Gilbreath \& Karimi, 2012).
When employees choose to be present at work while ill, they put their colleagues at health risk. The newly effected employees deal with illness either through presenteeism or absenteeism, thus effecting productivity and profit loss for the organization (Prater \& Smith, 2011). Presenteeism alone is responsible for loss of billions of dollars (Hemp, 2004; Weaver, 2010).With organizational structures becoming leaner, lesser number of employees are available to offset the loss of productivity that is caused due to presenteeism (Gilbreath \& Karimi, 2012). Managing presenteeism effectively could result in a competitive advantage for firms (Hemp, 2004; Johns, 2010).

Supervisor behavior plays a key role on employee productivity which is defined by the leadership style followed by a supervisor. It has been defined in various ways. Leadership can be 'a behavior enacted through communication' (Holladay and Combs, 1993). It may be 'a form of influence' (Hersey, 1984), 'the ability to guide followers toward shared goals' (Bryman, 1992) or 'simply something a leader does' (Fleishman, 1973). As times have progressed, organizations have moved towards a knowledge economy and new leadership theories too have emerged giving more attention to the relationship of a leader with their members. The leadership style helps to understand leadership behavior which in turn helps to understand how circumstances at work influence employee presenteeism and productivity.

Transactional leadership refers to 'the exchange relationship among leaders and followers in order to meet their own selfinterest' (Bass, 1999). It may be in the form of contingent reward where through direction and participation, the transactional leader clarifies for the follower as to what needs to be done to be rewarded for their efforts. It may take the form of either active or passive management- by- exception whereby in active management- by exception the leader monitors the performance of the follower and takes 
corrective action if the follower fails to meet the desired standards, and passive management- by- exception the leader takes action only when a problem arises. Some studies have observed a positive relationship between transactional leadership style and job performance (Shah \& Hamid 2015; Skakon et al., 2010).

Transformational leadership refers to a leader encouraging its members and making them look and act beyond their own interest through idealized influence (charisma), inspiration, intellectual stimulation or individualized consideration. Research on transformational leadership reveals that this leadership style is positively correlated to satisfaction at job (Neilsen et al., 2008; Skakon et al., 2010) and less burnout (Hetland, et al., 2007).

A laissez faire leader avoids any communication with the group members in decision making and supervisory responsibility. He believes in giving the employees the freedom to make their decisions, set their goals and do problem solving independently. Results concerning laissez faire leadership style have been mixed regarding stress and job satisfaction. Some studies found it to have an association with increased psychological distress and job strain (Nyberg, et al., 2009) while Skakon et al. found no such association.

Johns, 2010 states that 'presenteeism may cause more loss than absenteeism'. It is important that management and employees work together to reduce its repercussions. Leadership behavior plays a significant role to influence employee's health, productivity and other job related outcomes which may influence employee presenteeism within the firm (Gilbreath \& Karimi, 2012; Madlock, 2008; Nielsen et al., 2008; Pourbarkhordari et al., 2016; Shah \& Hamid, 2015). Interpersonal relationships among employees and supervisors have great psychological job outcomes. Work stress and dissatisfaction usually emanate from the nature of work and deteriorating relationship between workers and supervisors. Psychosocial factors such as job demands and control differ among genders and policies need to be developed on workplace environment and psychosocial factors (Gimeno et al., 2004).

The quality of work life can be improved through healthy work environments (Gilbreath \& Karimi, 2012; Gimeno et al., 2004; Pourbarkhordari et al., 2016). The organizational leadership is responsible for creating and maintaining a psychologically healthy work environment. The management can only be convinced to make efforts in this direction when they are made to realize the effect of illness on workforce productivity (Hemp, 2004). Similarly, investment in employee screening, treatment, education may help offset the issue of presenteeism and reap significant productivity gains. Thus this expense should not be taken as a cost, rather it should be considered as an investment into the organization's future employee wellbeing (Hemp 2004; Weaver 2010).

A number of studies have been conducted worldwide on presenteeism and leadership styles, however in Pakistan limited work has been done to understand the impact of leadership style and presenteeism among local healthcare professionals. Exploring this area may help supervisors to understand the influence of different leadership styles on employees and how healthier teams and work environments could be built to avoid presenteeism thus maximizing their team's potential and productivity. The objective of this study is to determine the relationship of leadership style (transactional, transformational and laissez faire) with employee presenteeism among the Pakistani health care professionals.

\section{Hypotheses}

H1: Transactional leadership style has no impact on employee presenteeism.

H2: Transformational leadership style has no impact on employee presenteeism. 
H3: Laissez faire leadership style has no impact on employee presenteeism.

\section{Methodology}

Primary data were collected using a structured close ended questionnaire which was adopted by a study on employee presenteeism. The survey questionnaire briefly explained the study objective and was divided into three sections consisting of close-ended questions. The first section consisted of demographic data such as gender, age, size of the organization and frequency of meeting with supervisor. The second section was based on the three leadership styles with 12 questions for transformational leadership style, 6 questions on transactional leadership style and 3 questions on laissez faire style. The third section consisted of 8 questions pertaining to employee presenteeism. The second and third sections of the survey were designed to gauge respondent's agreement using a five point likert scale of agreement. Points allocated to the responses were $-2=$ strongly disagree, $-1=$ disagree, $0=$ neutral, $1=$ agree, $2=$ strongly agree. The research focused on two variables, leadership styles (transactional, transformational, laissez faire) as the independent variable and employee presenteeism as the dependent variable. Convenience sampling was used for the collection of primary data. The respondents consisted of doctors, hospital management and pharmaceutical professionals. The survey was conducted after taking the consent of the respondents and took approximately 7-10 minutes to complete.

Responses were coded and were entered into SPSS Version 21. The descriptive statistics were carried out to analyze the demographic data in frequency and percentage. Linear regression was used to test each hypothesis. Descriptive analysis was carried out and data were expressed in frequency and percentage.

\section{Results}

The demographics of the sample reveal that the questionnaire was answered by 65 males and 63 females, which constitutes about 51\% and $49 \%$ respectively. Five age ranges were defined; 20-25, 26- 30, 31-35, 36-40, 41-45 years. $24 \%$ respondents fell in the age bracket of $20-25,36 \%$ in $26-30,18 \%$ in 31 $35,15 \%$ in $36-40$ and $7 \%$ in $41-45$ years. 16 Respondents belonged to organizations with less than 50 employees and 84 from more than 50 employees in an organization. In order to have a variety in data and to gauge three leadership styles under the current study, the frequency of interaction of the respondents with the manager in a week was also gauged. $25 \%$ of the respondents met their managers once a week, $65 \%$ met with their managers more than once a week and $10 \%$ hardly met with their managers.

The data indicate diversity and variety among the respondents. Table 1 summarizes the results of the survey demographics. 
Table 1: Demographic Data of Study

\begin{tabular}{|c|c|}
\hline Variable & Response in \% \\
\hline \multicolumn{2}{|l|}{ Gender } \\
\hline Male & 51 \\
\hline Female & 49 \\
\hline \multicolumn{2}{|l|}{ Age } \\
\hline $20-25$ & 24 \\
\hline $26-30$ & 36 \\
\hline $31-35$ & 18 \\
\hline $36-40$ & 15 \\
\hline $41-45$ & 7 \\
\hline \multicolumn{2}{|l|}{ Organization size } \\
\hline Less than 50 employees & 16 \\
\hline More than 50 employees & 84 \\
\hline \multicolumn{2}{|c|}{ Frequency of interaction with manager } \\
\hline Once & 25 \\
\hline More than once & 65 \\
\hline Not applicable & 10 \\
\hline
\end{tabular}

Table: 2: Cronbach Alpha: Test for Reliability

\begin{tabular}{|c|c|c|}
\hline Factor & Cronbach's Alpha & N of Items \\
\hline Transformational & .924 & 12 \\
\hline Transactional & .857 & 6 \\
\hline Laissez Faire & .726 & 3 \\
\hline Presenteeism & .920 & 8 \\
\hline
\end{tabular}

The data for every section in the questionnaire regarding leadership styles and presenteeism among employees were checked for inter-item consistency and 
reliability. The Cronbach value for each was more than the benchmark value of 0.7 for
Cronbach Alpha. This shows that the reliability test values variables is excellent.

Table 3: Correlations

\begin{tabular}{|c|c|c|c|c|c|}
\hline \multicolumn{1}{|c|}{} & Transformational & Transactional & Laissez faire & Presenteeism \\
\hline \multirow{5}{*}{ Transformational } & $\begin{array}{c}\text { Pearson } \\
\text { Correlation }\end{array}$ & 1 & $.789^{* *}$ & $.719^{* *}$ & -.094 \\
\cline { 2 - 6 } & Sig. (2-tailed) & & .000 & .000 & .290 \\
\cline { 2 - 6 } Transactional & $\mathrm{N}$ & 128 & 128 & 128 & 128 \\
\hline \multirow{5}{*}{ Laissez Faire } & $\begin{array}{c}\text { Pearson } \\
\text { Correlation }\end{array}$ & $.789^{* *}$ & 1 & $.833^{* *}$ & -.088 \\
\cline { 2 - 6 } & Sig. (2-tailed) & .000 & & .000 & .321 \\
\cline { 2 - 6 } & $\mathrm{N}$ & 128 & 128 & 128 & 128 \\
\cline { 2 - 6 } & $\begin{array}{c}\text { Pearson } \\
\text { Correlation }\end{array}$ & $.719^{* *}$ & $.833^{* *}$ & 1 & -.033 \\
\cline { 2 - 6 } & Sig. (2-tailed) & .000 & .000 & & .710 \\
\hline \multirow{5}{*}{ Presenteeism } & $\mathrm{N}$ & 128 & 128 & 128 & 128 \\
\cline { 2 - 6 } & $\begin{array}{c}\text { Pearson } \\
\text { Correlation }\end{array}$ & -.094 & -.088 & -.033 & 1 \\
\cline { 2 - 6 } & Sig. (2-tailed) & .290 & .321 & .710 & 128 \\
\cline { 2 - 6 } & $\mathrm{N}$ & 128 & 128 & 128 & \\
\hline
\end{tabular}

**. Correlation is significant at the 0.01 level (2-tailed).

The table reveals that correlation is statistically significant at $1 \%$ significance level $(\mathrm{p}<0.05)$. The correlation indicated through the Pearson $r$ statistics among all three leadership styles; transformational, transactional and laissez faire is positive and significant, thus indicating a significant relationship among the variables. On the other hand, $r$ statistics for presenteeism with all the three leadership styles is statistically insignificant at significance level $(\mathrm{p}<0.05)$. This indicates that there is no relation among the dependent variable presenteeism and the independent variables, the three leadership styles.

\section{Regression for Transformational Leadership Style}

Table 4: Model Summary

\begin{tabular}{|l|c|c|c|c|}
\hline \multicolumn{5}{|c|}{ Model Summary } \\
\hline MModel & $\mathrm{R}$ & R Square & $\begin{array}{c}\text { Adjusted R } \\
\text { Square }\end{array}$ & Std. Error of the Estimate \\
\hline 1 & $.109 \mathrm{a}$ & .012 & .004 & .99000 \\
\hline \multicolumn{5}{|c|}{ a. Predictors: (Constant), transformational } \\
\hline \multicolumn{4}{|c|}{} \\
\hline
\end{tabular}

The model summary explains the amount of variability in the dependent variable as explained by the independent variable. The value of adjusted $R$ is of 0.004 . This means that approximately $0.4 \%$ of the variability of the dependent variable 'presenteeism' is explained by the independent variable 'transformational leadership style'. The remaining variance is unexplained. 
Table 5: ANOVAa

\begin{tabular}{|c|c|c|c|c|c|c|}
\hline \multicolumn{2}{|c|}{ Model } & Sum of Squares & $\mathrm{df}$ & Mean Square & $\mathrm{F}$ & Sig. \\
\hline \multirow{3}{*}{1} & Regression & 1.395 & 1 & 1.395 & 1.424 & $235 \mathrm{~b}$ \\
\cline { 2 - 7 } & Residual & 115.651 & 118 & .980 & & \\
\cline { 2 - 7 } & Total & 117.047 & 119 & & & \\
\hline \multicolumn{7}{|c|}{ a. Dependent Variable: Presenteeism } \\
\hline
\end{tabular}

The ANOVA table shows the overall fitness of the model. It is prominent from the sig. value
0.235 which is more than $\mathrm{p}<0.05$ that the overall model is insignificant.

Table 6: Coefficients

\begin{tabular}{|c|c|c|c|c|c|c|}
\hline \multicolumn{2}{|c|}{ Model } & \multicolumn{2}{|l|}{ Unstandardized Coefficients } & $\begin{array}{c}\text { Standardized } \\
\text { Coefficients }\end{array}$ & \multirow{2}{*}{ Sig. } & \\
\cline { 3 - 6 } \multicolumn{2}{|c|}{} & B & Std. Error & Beta & & \\
\hline \multirow{2}{*}{1} & (Constant) & -.058 & .095 & & -.611 & .542 \\
\cline { 2 - 6 } & transformational & -.125 & .105 & -.109 & -1.193 & .235 \\
\hline \multicolumn{7}{|l|}{ Dependent Variable: Presenteeism } \\
\hline
\end{tabular}

The Coefficients' table shows the significance of each individual independent variable in explaining the dependent variable. The unstandardized coefficient (B) value shows the relationship and magnitude between the dependent variable 'presenteeism' and the independent variable 'transformational leadership styles'. The negative value of beta -0.125 means that there is a negative relationship between the predictor and the dependent variable. The sig value of 0.235 is greater than $\mathrm{p}<0.05$ indicating that the predictor is making insignificant contribution in the model.

\section{Regression For Transactional Leadership Style}

Table 7: Model Summary

\begin{tabular}{|c|c|c|c|c|}
\hline Model & $\mathrm{R}$ & R Square & Adjusted R Square & $\begin{array}{c}\text { Std. Error of the } \\
\text { Estimate }\end{array}$ \\
\hline 1 & $.088 \mathrm{a}$ & .008 & -.001 & .99070 \\
\hline
\end{tabular}

The value of adjusted $R$ is of -0.001 which explains the variability of the dependent variable 'presenteeism' with the independent variable 'transactional leadership style'. 
Table 8: ANOVA

\begin{tabular}{|c|c|c|c|c|c|c|}
\hline \multicolumn{2}{|c|}{ Model } & Sum of Squares & $\mathrm{df}$ & Mean Square & $\mathrm{F}$ & Sig. \\
\hline \multirow{3}{*}{1} & Regression & .914 & 1 & .914 & .931 & $.336 \mathrm{~b}$ \\
\cline { 2 - 7 } & Residual & 116.797 & 119 & .981 & & \\
\cline { 2 - 7 } & Total & 117.712 & 120 & & & \\
\hline
\end{tabular}

The ANOVA table shows the overall fitness of the model. It is prominent from the sig. value
0.336 which is more than $\mathrm{p}<0.05$ that the overall model is insignificant.

Table 9: Coefficients

\begin{tabular}{|c|c|c|c|c|c|c|}
\hline \multicolumn{2}{|c|}{ Model } & \multicolumn{2}{|l|}{ Unstandardized Coefficients } & $\begin{array}{c}\text { Standardized } \\
\text { Coefficients }\end{array}$ & \multirow{2}{*}{ S ig. } & \\
\cline { 3 - 5 } \multicolumn{2}{|c|}{} & B & Std. Error & Beta & & \\
\hline \multirow{2}{*}{1} & (Constant) & -.065 & .094 & & -.690 & .492 \\
\cline { 2 - 7 } & transactional & -.097 & .101 & -.088 & -.965 & .336 \\
\hline \multicolumn{2}{|l|}{ Dependent Variable: Presenteeism }
\end{tabular}

The beta value shows the magnitude and relationship between presenteeism and transformational leadership styles. The negative value of beta -0.097 means that there is a negative relationship between the predictor i.e. transactional leadership and presenteeism which is the dependent variable. Sig value of 0.336 is greater than $\mathrm{p}<0.05$ indicating that the predictor is making insignificant contribution in the model.

\section{Regression for laissez faire leadership style}

Table 10: Model Summary

\begin{tabular}{|c|c|c|c|c|}
\hline Model & $\mathrm{R}$ & R Square & $\begin{array}{c}\text { Adjusted R } \\
\text { Square }\end{array}$ & $\begin{array}{c}\text { Std. Error of the } \\
\text { Estimate }\end{array}$ \\
\hline 1 & $.040 \mathrm{a}$ & .002 & -.007 & .98987 \\
\hline \multicolumn{4}{l}{} \\
\hline
\end{tabular}

The value of adjusted $R$ is of -0.007 which explains the variability of the dependent

variable 'presenteeism' with the independent variable 'laissez faire leadership style'.

Table 11: ANOVA

\begin{tabular}{|l|c|c|c|c|c|c|}
\hline \multicolumn{2}{|c|}{ Model } & Sum of Squares & $\mathrm{df}$ & Mean Square & $\mathrm{F}$ & Sig. \\
\hline \multirow{3}{*}{1} & Regression & .191 & 1 & .191 & .195 & $.660 \mathrm{~b}$ \\
\cline { 2 - 7 } & Residual & 118.560 & 121 & .980 & & \\
\cline { 2 - 7 } & Total & 118.751 & 122 & & & \\
\hline
\end{tabular}

Syeda Nadia Bokhari, Nawaz Ahmad and Syed Irfan Hyder (2017), Journal of Southeast Asian Research, DOI: $10.5171 / 2017.255072$ 
The overall fitness of the model is seen by the ANOVA table. Sig. value of 0.660 which is more than $\mathrm{p}<0.05$ shows that the overall model is insignificant.

Table 12: Coefficients

\begin{tabular}{|c|c|c|c|c|c|c|}
\hline \multicolumn{2}{|c|}{ Model } & \multicolumn{2}{|l|}{ Unstandardized Coefficients } & $\begin{array}{c}\text { Standardized } \\
\text { Coefficients }\end{array}$ & \multirow{2}{*}{ Sig. } & \\
\cline { 3 - 5 } \multicolumn{2}{|c|}{} & B & Std. Error & Beta & & \\
\hline \multirow{2}{*}{1} & (Constant) & -.090 & .094 & & -.960 & .339 \\
\cline { 2 - 7 } & LaissezFaire & -.046 & .104 & -.040 & -.442 & .660 \\
\hline
\end{tabular}

The negative value of beta -0.046 means that a negative relationship exists between the predictor and the dependent variable. The sig value of 0.660 is greater than $p<0.05$ which indicates that the predictor is making insignificant contribution in the model.

\section{Backward Method}

Using the backward method, the insignificant variables were removed. The result confirms that all the three leadership styles were insignificant.

\section{Discussion}

The internal consistency reliability and validity for the measures of leadership styles and presenteeism were acceptable. Statistics revealed that all three leadership styles were correlated but none of these styles had a correlation with job stress presenteeism. Regression analysis further revealed that the three leadership styles have no impact on employee presenteeism. Backward regression confirmed that all the three leadership styles, the transformational, the transactional and laissez faire leadership styles have no impact on presenteeism. Most literature supports the relationship between leadership styles and presenteeism (Gilbreath \& Karimi, 2012; Johns, 2010; Madlock, 2008; Nielsen et al, 2008). In previous studies, the relation between transformational leadership style and presenteeism was seen to exist significantly (Gilbreath \& Karimi, 2012). The relationship between transactional leadership has been seen to have an inverse relationship with presenteeism (Munir et al., 2010). In the case of the current study, there is no impact of transactional leadership style on presenteeism. Results for laissez faire style and presenteeism have been mixed. Some studies show a relationship between the two (Nyberg, 2009) while some indicate that there is no relationship between laissez faire and presenteeism (Skakon et al., 2010). This study reveals that laissez faire leadership style has no impact on presenteeism.

\section{Conclusion and Limitations}

The outcome of the study revealed that none of the leadership styles (transactional, transformational and laissez faire) have an impact on employee presenteeism. All the variables proved to be insignificant predictors of employee presenteeism thus concluding that there is no impact of leadership style on presenteeism among the Pakistani health care professionals.

This study had its own limitations. Respondents were unaware of the leadership style that was being followed at their organization. This created the occurrence of content non-responsivity where respondents respond without regard to item content by carelessly and randomly responding (Nichols, Greene, Shmolck, 1989). Furthermore some responses were influenced by respondent falsification due to peer pressure and office politics. 


\section{References}

Absenteeism, 2006. American Heritage Dictionary of the English language. Retrieved from

http://www.answers.com/topic/absenteeis m\#ixzz1EZ01Pgqc

Aronsson, G., Gustafsson, K. and Dallner, M., 2000. Sick but yet at work. An empirical study of sickness presenteeism. Journal of Epidemiology and Community Health, 54(7), pp.502-509.

Bass, B.M., 1999. Two decades of research and development in transformational leadership. European Journal of Work and Organizational Psychology, 8(1), pp.9-32.

Bryman, A., 1992. Charisma and leadership in organizations. Sage Publications.

Cooper, C. L. 1994. The costs of healthy work organizations. In C. L. Cooper, \& S. Williams (eds.)., Creating Healthy Work Organizations. John Wiley \& Sons.

Fleishman, E.A., 1973. Twenty years of Consideration and Structure. In E. A. Fleishman, \& JG Hunt (eds.). Current Development in the Study of Leadership. Southern Illinois University.

Gilbreath, B. and Karimi, L., 2012. Supervisor behavior and employee presenteeism. International Journal Leadership Study, 7(1), pp.114-131.

Gimeno, D., Benavides, F.G., Amick, B.C., Benach, J. and Martínez, J.M., 2004. Psychosocial factors and work related sickness absence among permanent and nonpermanent employees. Journal of Epidemiology and Community Health, 58(10), pp.870-876.

Hemp, P., 2004. Presenteeism: at work-but out of it. Harvard Business Review, 82(10), pp.49-58.
Hershey, P., 1985. The situational leader. Center for Leadership Studies.

Hetland, H., Sandal, G.M. and Johnsen, T.B., 2007. Burnout in the information technology sector: Does leadership matter?. European Journal of Work and Organizational Psychology, 16(1), pp.58-75.

Holladay, S.J. and Coombs, W.T., 1993. Communicating visions an exploration of the role of delivery in the creation of leader charisma. ManagementCommunication Quarterly, 6(4), pp.405-427.

Johns, G., 2010. Presenteeism in the workplace: A review and research agenda. Journal of Organizational Behavior, 31(4), pp.519-542.

Johnson, J.A., 2005. Ascertaining the validity of individual protocols from web-based personality inventories. Journal of research in personality, 39(1), pp.103-129.

Madlock, P.E., 2008. The link between leadership style, communicator competence, and employee satisfaction. Journal of Business Communication,45(1), pp.61-78.

Munir, F., Nielsen, K. and Carneiro, I.G., 2010. Transformational leadership and depressive symptoms: A prospective study. Journal of affective disorders, 120(1), pp.235-239.

Nichols, D.S., Greene, R.L. and Schmolck, P., 1989. Criteria for assessing inconsistent patterns of item endorsement on the MMPI: Rationale, development, and empirical trials. Journal of Clinical Psychology, 45(2), pp.239-250.

Nielsen, K., Randall, R., Yarker, J. and Brenner, S.O., 2008. The effects of transformational leadership on followers' perceived work characteristics and psychological well-being: A longitudinal study. Work \& Stress, 22(1), pp.16-32.

Nyberg, A., Alfredsson, L., Theorell, T., Westerlund, H., Vahtera, J. and Kivimäki, M., 
2009. Managerial leadership and ischaemic heart disease among employees: the Swedish WOLF study. Occupational and environmental medicine, 66(1), pp.51-55.

Pourbarkhordari, A., Zhou, E. H., and Pourkarimi, J., 2016. Role of transformational leadership in creating a healthy work environment in business setting. European Journal of Business and Management, 8(3).

Prater, T. and Smith, K., 2011. Underlying factors contributing to presenteeism and absenteeism. Journal of Business \& Economics Research, 9(6), p.1.

Shah, S.M.M., Hamid, A. and Bin, K., 2015. Transactional Leadership and Job Performance: An Empirical
Investigation. Sukkur IBA Journal of Management and Business, 2(2), pp.69-81.

Skakon, J., Nielsen, K., Borg, V. and Guzman, J., 2010. Are leaders' well-being, behaviours and style associated with the affective wellbeing of their employees? A systematic review of three decades of research. Work \& Stress, 24(2), pp.107-139.

Weaver, R., 2010. Cost of presenteeism surpasses absenteeism. Retrieved from http://www. examiner. com/human-capitalin-detroit/cost-of-presenteeism-surpassesabsenteeism [Links].

Whitehouse, D., 2005. Workplace presenteeism: how behavioral professionals can make a difference. Behavioral healthcare tomorrow, 14(1), pp.32-36. 